\title{
Phosphate solubilizing bacteria promote growth and enhance nutrient uptake by wheat
}

\author{
Aniruddha Sarker ${ }^{1}$, Nur Mohammad Talukder ${ }^{1} \&$ Md. Tofazzal Islam ${ }^{2} \bowtie$
}

\begin{abstract}
Phosphorus (P) fixation limits availability of $P$ to plants in tropical soil, which is a major constraint for crop production. The aim of our research was to isolate, screen and characterize phosphate solubilizing bacteria (PSB) from wheat and evaluate their efficacy in $P$ nutrition in wheat. Upon screening, 9 isolates showing varying level of phosphate solubilizing activity in both agar plate and broth assays using Pikovskaya's medium were obtained. The $\mathrm{pH}$ of the culture media was decreased with increased bacterial growth suggesting that they might secrete organic acids to solubilize insoluble phosphorus. In vitro wheat seedling bioassay with two superior PSB isolates (PSB1 and PSB8) and varying sources of $P$ revealed that both isolates significantly enhanced seedling growth (shoot and root length, shoot and root dry weight) and nutrient contents (\%N, \%P and \%K) in plant tissue compared to control (no PSB). The performance of PSB8 was superior to PSB1 in respect of all the parameters studied. The PSB8 was tentatively identified as Pseudomonas sp. through $16 \mathrm{~S}$ rRNA gene sequencing. Our results suggest that Pseudomonas sp. PSB8 isolated from wheat might be useful for improving $P$ nutrition in wheat in soils with low available $P$.
\end{abstract}

Received: 16 March 2014 / Accepted: 14 May 2014 / Published online: 6 June 2014

(C) Horizon e-Publishing Group

CITATION

Sarker, A., Talukder, N. M., \& Islam, M. T. (2014). Phosphate solubilizing bacteria promote growth and enhance nutrient uptake by wheat. Plant Science Today, 1(2), 86-93. http://dx.doi.org/10.14719/pst.2014.1.2.25

AUTHORS' AFFILIATION

1 Department of Agricultural Chemistry, Bangladesh Agricultural University, Mymensingh-2202, Bangladesh.

2 Department of Biotechnology, Bangabandhu Sheikh Mujibur Rahman Agricultural University, Salna, Gazipur-1706, Bangladesh.

CORRESPONDENCE (区)

Md. Tofazzal Islam, Email: tofazzalislam@yahoo.com
Keywords: Phosphate solubilizing bacteria; wheat; P nutrition; Pseudomonas sp.

\section{Introduction}

Phosphorus (P) is one of the essential mineral macronutrients, which is required for maximizing the yield of crops (Griffith, 2009). In soils, P may exist in many different forms, which can be thought of existing in 3 "pools": solution P, active P and fixed P (Busman, Nalepa, \& Dobryniewska, 2009). Generally, a major portion of soil $P$ remains as insoluble forms with cations $\mathrm{Al}^{3+}$ and $\mathrm{Fe}^{3+}$ in acidic soils, and $\mathrm{Ca}^{2+}$ in calcarious soils), which are usually unavailable for uptake by crop plants (Abd-Alla, 1994; Yadav \& Dadarwal, 1997). It has been assumed that, global crop yield up to $30-40 \%$ of arable land is limited by low $\mathrm{P}$ availability (Von Uexkull \& Mutert, 1995). In Bangladesh, a greater portion of soil contains low to medium amounts of available P. A significant reduction in the use of phosphatic fertilizer could be achieved if in some way, solubilization of soil insoluble P is made available to crop plants (Rodriguez \& Fraga, 1999; Vessey, 2003; Thakuria et al., 2004; Islam et al., 2007; Islam \& Hossain, 2012; Sarker, Islam, Biswas, Alam, \& Talukder, 2012). Some bacterial species can mineralize and solubilize soil organic and inorganic $\mathrm{P}$ (Hilda \& Fraga, 2000; Khiari \& Parent, 2005; Islam et al., 2007; Islam \& Hossain, 2012; Sarker et al., 2012).

Application of phosphate solubilizing bacteria (PSB) as bioinoculants can solubilize the fixed soil $\mathrm{P}$ and applied phosphates resulting in higher crop yields (Gull, Hafeez, Saleem, \& Malik, 2004). Therefore, PSB are critical for the transfer of $\mathrm{P}$ from poorly available soil pools to plant available forms and are important for maintaining $\mathrm{P}$ in readily available pools of soil (Fankem et al., 2006). Seed or soil inoculation with PSB has been known to improve solubilization of fixed soil $\mathrm{P}$ and applied phosphates resulting in higher crop yields (Abd-Alla, 1994; Jones \& Darrah, 1994; Yadav \& Dadarwal, 1997). Several lines of evidence suggest that application of PSB improves plant P nutrition and increases the yield of cereals including wheat (Afzal \& Asghari, 2008; Ashrafuzzaman et al., 2009; Islam 
\& Hossain 2012). Therefore, isolation and characterization of PSB from wheat plants grown in acidic soils are considered as interesting research target for discovering novel elite strains of PSB (Islam \& Hossain, 2012). Scant information is available regarding isolation, and identification of PSB from the rhizosphere of wheat and their application for $P$ nutrition in wheat in the acidic soils of Bangladesh. However, some successful attempts have been made to isolate, screen and characterize PSB from rhizosphere of different crop plants and test their efficacy in crops grown in the acidic soils of Bangladesh (Rahman, Talukder, \& Islam, 2005; Islam et al., 2007; Alam, Talukder, Islam, \& Rahman, 2008; Sarker et al., 2012). The objectives of current study were to isolate, screen and characterize PSB from the rhizoplane of wheat; evaluate phosphate solubilizing capacity of the isolated PSB and their growth at different $\mathrm{pH}$ on culture medium, and assess performance of some superior PSB on growth and nutrient contents in wheat seedlings.

\section{Materials and methods}

Preparation of root samples and isolation of rhizoplane bacteria

The root samples were collected from the 20 day-old wheat seedlings grown at the Analytical laboratory of Department of Agricultural Chemistry using sterile forceps and needles. The roots were cut into small pieces and homogenized by crushing followed by vigorous shaking by a vortex mixture for $1 \mathrm{~min}$ in $20 \mathrm{~mL}$ distilled water in a sterile test tube. Homogenate was diluted 100 -fold by a dilution series down to $1 \times 10^{-6}$. Pikovskaya's (PVK) medium was used for isolating possible potential PSB (Pikovskaya, 1948). Exactly $100 \mu \mathrm{L}$ aliquot of each sample (ca. $1 \times 10^{-6}$ dilution series) were taken and spread over the PVK medium for identification of watery clear halo zone of the bacterial strains. From the mixtures of different bacterial strains, the potential PSB were detected and isolated on the basis of clear halo zone (Islam \& Hossain, 2012). All inoculated plates were incubated at $25^{\circ} \mathrm{C}$ for 2 days and observation was continued for 4 days.

\section{Screening of phosphate solubilizing bacteria on agar assay}

Mineral phosphate solubilization activities of isolated bacterial strains were tested by plate assay qualitatively (Islam et al., 2007). Briefly, a colony of bacterium was taken from each isolate using sterile toothpicks and inoculating loop and plated onto PVK agar medium containing tricalcium phosphate, making a groove on the medium and incubated at $25^{\circ} \mathrm{C}$ for $72 \mathrm{~h}$. The halo zone of solubilized $\mathrm{P}$ and colony diameters were measured after 7 days of incubation of plates at $25^{\circ} \mathrm{C}$. Phosphate solubilizing capacity was calculated in terms of phosphate solubilization index (PSI). The isolates showing PSI $>2$ have been considered as PSB (Sarker et al., 2012). The ratio of total diameter (colony + halo zone) and the colony diameter was measured as PSI (Edi Premono, Moawad, \& Vlek, 1996).

Quantitative estimation of phosphate solubilization in broth assay

The quantitative bioassay was carried out using Erlenmeyer flasks (100 mL) containing $50 \mathrm{~mL}$ PVK broth inoculated using bacterial isolates with approximately $1 \times$ $10^{8}-10^{9}$ Colony Forming Units (CFU) per mL. The bacteria were inoculated in the medium having $\mathrm{pH} 7.0$, which was adjusted before autoclaving the medium. The flasks were incubated at $25^{\circ} \mathrm{C}$ in a shaker for $48 \mathrm{~h}$ at $100 \mathrm{rpm}$. The cultures were collected for centrifugation for $10 \mathrm{~min}$ at $5500 \mathrm{rpm}$. The supernatant was decanted and filtered through Whatman No. 41 filter paper (Islam et al., 2007). The available $\mathrm{P}$ content in the supernatant was estimated by phospho-molybdate blue complex colorimetric method at $660 \mathrm{~nm}$ wavelength (Olsen, Col, Watanable, \& Dean, 1954, Alam et al., 2008). Each treatment was replicated three times and data were expressed as the mean value \pm standard error (SE).

\section{Bacterial growth and $p H$ value of the culture medium}

To analyze whether bacteria can grow in a range of $\mathrm{pH}$ 5.5 to 8.5 and to test their ability to change the $\mathrm{pH}$ value of the medium, the most superior five strains of PSB were inoculated separately in test tubes $(18 \times 1.6 \mathrm{~cm})$ containing $50 \mathrm{~mL}$ of PVK broth at varying $\mathrm{pH}$ levels. Bacteria were grown in a shaking incubator (100 rpm) for 8 days at $25^{\circ} \mathrm{C}$. The optical density of the bacterial supernatant after precipitation of insoluble tri-calcium phosphates and $\mathrm{pH}$ value of the medium were estimated after 2 days intervals using a spectrophotometer (ALPO, Germany) at $595 \mathrm{~nm}$ and a pH meter (Horiba, B-212, Kyoto, Japan), respectively (Islam et al., 2007). Each treatment was replicated three times and data were expressed as the mean value.

Performance evaluation of superior bacterial strains through wheat seedling bioassay

The $500 \mathrm{~mL}$ Erlenmeyer flasks were selected for this in vivo culture of the wheat seedlings. Two strains PSB1 (PSI 3.936 and $\mathrm{P}$ solubilization in broth assay $66.32 \mathrm{mg} / \mathrm{L}$ ) and PSB8 (PSI 4.08 and P solubilization in broth assay 61.78 $\mathrm{mg} / \mathrm{L}$ ) were selected for this study. The control treatment (no PSB) was designated as PSB0. They were cultured in PVK broth medium for 3 days at $25 \pm 1{ }^{\circ} \mathrm{C}$ in a shaker at $100 \mathrm{rpm}$. When growth was found optimum; the cultures were checked for purity and population. Then these were centrifuged at $5500 \mathrm{rpm}$ repeatedly with deionized distilled water for three times. Then these bacterial cells without any culture media were suspended in sterilized water. These bacterial suspensions were used for seed inoculation of wheat for in vivo culture. The selected 
variety of wheat was Shatabdi. Seeds were surface sterilized by using $20 \%$ Clorox for $1 \mathrm{~min}$ and then washed by distilled water for three times. The seeds were then soaked in the bacterial suspension ( $c a .1 \times 10^{10}$ ) for $3 \mathrm{~h}$ (Alam et al., 2008).

Subsequently, these bacteria-coated seeds were kept in blotting paper for absorbing extra aqueous mass from the seeds and then used for in vivo culture on agar (1\%) containing Hoagland's media in 500 mL Erlenmeyer flasks for 20 days. Different sources of $\mathrm{P}$ used in the study were designated as $\mathrm{P}_{0}=$ No $\mathrm{P}$ fertilization; $\mathrm{P}_{1}=0.5 \% \mathrm{P}$ as Triple superphosphate (TSP); $\mathrm{P}_{2}=0.5 \% \mathrm{P}$ as $\mathrm{Ca}_{3}\left(\mathrm{PO}_{4}\right)_{2}$ and $\mathrm{P}_{3}=$ $0.5 \% \mathrm{P}$ as $\mathrm{AlPO}_{4}$. After 20 days, the seedlings were harvested and separated into shoot and root for analyses of different growth parameters and nutrient contents in plant tissues. Each treatment was replicated for three times.

\section{Determination of nutrient content in plant tissues}

The estimation of total nitrogen was made by the semi-micro Kjeldahl method (Page, Miller, \& Keeney, 1982). The $P$ content of plant extract was determined colorimetrically by stannous chloride method (Olsen et al., 1954) and potassium was estimated by flame emission spectrophotometer (Page et al., 1982).

\section{Molecular identification of active bacteria}

For the determination of $16 \mathrm{~S}$ rRNA sequence of PSB8, chromosomal DNA extraction was done using the commercial DNA extraction kit (ATM TM Genomic DNA Extraction Kit) and quantified using lambda DNA marker after agarose gel electrophoresis. The $16 \mathrm{~S}$ rRNA region was amplified by PCR using $27 \mathrm{~F}$ and $1492 \mathrm{R}$ universal primer. Thermal cycling was performed with Mastercycler ${ }^{\circledR}$ Gradient (Eppendorf, Hamburg, Germany). PCR direct-sequencing was done using Big Dye Terminator Cycle Sequencing Ready Reaction kit (Applied Biosystems, Foster City, CA, USA). Labeled PCR-direct mixture was purified and analyzed by sequencer (ABI Prism ${ }^{\circledR} 310$ Genetic Analyzer, Applied Biosystems) according to the manufacturer's instructions. Forward and reverse sequences were combined using the Lasergene version 7.1 programs. The 16S rRNA gene sequence data of the PSB8 were subjected to BLASTN search using NCBI website (http://blast.ncbi.nlm.nih.gov/Blast.cgi) for DNA-DNA homology study.

\section{Experimental design and data analysis}

The in vivo experiment was laid out in Randomized Complete Block Design (RCBD) having two factors (both factor with similar preference) with 3 replications. The statistical analysis of the experiment was carried out using statistical computer package MSstat-C and PLABstat. The ANOVA followed by Duncan's Multiple Range Test (DMRT) was used to analyze the data.

\section{Results}

Isolation, screening, and phosphate solubilization by PSB

Nine bacterial isolates (PSB1-9) were isolated from the rhizoplane of wheat and purified by repeated streak culture on NBA medium. To screen whether these bacterial isolates can solubilize phosphates from tricalcium phosphate, PVK agar medium was used in agar plate assay. The phosphate solubilisation index (PSI) of tested bacterial strains ranged from 2.14 to 4.08 (Table 1). Among the tested strains, PSB8 and PSB2 displayed maximum and minimum phosphate solubilization in agar medium, respectively.

The PSB isolates also showed varying level of phosphate solubilization in broth assay. It revealed that the trend of phosphate solubilization by PSB isolates in both agar and broth assays was more or less consistent. The highest phosphate solubilization was recorded in PSB1 $(66.32$ $\mathrm{mg} / \mathrm{L}$ ) followed by PSB8 (61.78 $\mathrm{mg} / \mathrm{L}$ ) (Table 1). The lowest performance was shown by PSB7 (28.35 mg/L). Considering the superior performances in both agar and broth assays, PSB1 and PSB8 were chosen for further evaluation of their effects on growth and nutrient uptake by wheat $c v$. Shatabdi in seedling assay.

Table 1. Phosphate solubilizing index and amount of phosphate solubilization by different bacterial isolates in agar and broth assay using Pikovskaya's medium

\begin{tabular}{ccc}
\hline Bacterial isolates & PSI* in agar assay $^{* *}$ & PSI in broth assay $(\mathbf{m g} / \mathbf{L})^{* *}$ \\
\hline PSB1 & $3.94 \pm 0.02$ & $66.32 \pm 3.5$ \\
PSB2 & $2.14 \pm 0.01$ & $38.36 \pm 1.8$ \\
PSB3 & $2.69 \pm 0.01$ & $41.29 \pm 2.6$ \\
PSB4 & $3.13 \pm 0.02$ & $48.58 \pm 2.5$ \\
PSB5 & $3.53 \pm 0.02$ & $51.59 \pm 3.2$ \\
PSB6 & $2.66 \pm 0.01$ & $39.06 \pm 2.4$ \\
PSB7 & $2.18 \pm 0.01$ & $28.65 \pm 1.5$ \\
PSB8 & $4.08 \pm 0.02$ & $61.78 \pm 5.8$ \\
PSB9 & $3.34 \pm 0.01$ & $54.32 \pm 4.3$ \\
\hline
\end{tabular}

* Phosphate solubilization index (PSI) $=$ (Halo + colony diameter) / colony diameter

**Mean \pm Standard Error (SE) 
Table 2. Interaction effect of PSB inoculation and different sources of $P$ on shoot length and root length of wheat seedlings at different days after inoculation (DAI)

\begin{tabular}{|c|c|c|c|c|c|}
\hline \multirow{2}{*}{$\begin{array}{c}\text { PSB inoculum } \\
\times \\
\text { Phosphorus } \\
\text { interaction }\end{array}$} & \multicolumn{4}{|c|}{ Shoot length $(\mathrm{cm})$} & \multirow{2}{*}{$\begin{array}{c}\text { Root length }(\mathrm{cm}) \\
\begin{array}{c}20 \text { DAI } \\
\text { (harvest) }\end{array}\end{array}$} \\
\hline & 5 DAI & 10 DAI & 15 DAI & $\begin{array}{c}20 \text { DAI } \\
\text { (harvest) }\end{array}$ & \\
\hline $\mathrm{PSB}_{0} \mathrm{P}_{0}$ & $2.6 \mathrm{e} \pm 0.01$ & $3.6 \mathrm{i} \pm 0.02$ & $5.8 \mathrm{f} \pm 0.01$ & $6.5 h \pm 0.04$ & $4.6 \mathrm{~d} \pm 0.03$ \\
\hline $\mathrm{PSB}_{0} \mathrm{P}_{1}$ & $2.7 \mathrm{de} \pm 0.02$ & $4.1 \mathrm{~g} \pm 0.04$ & $6.2 \mathrm{e} \pm 0.04$ & $7.4 \mathrm{f} \pm 0.02$ & $4.2 \mathrm{e} \pm 0.01$ \\
\hline $\mathrm{PSB}_{0} \mathrm{P}_{2}$ & $2.9 \mathrm{~d} \pm 0.01$ & $3.8 h \pm 0.01$ & $6.0 \mathrm{e} \pm 0.02$ & $7.1 \mathrm{~g} \pm 0.01$ & $4.7 d \pm 0.04$ \\
\hline $\mathrm{PSB}_{0} \mathrm{P}_{3}$ & $2.6 \mathrm{e} \pm 0.05$ & $3.8 h \pm 0.01$ & $5.9 \mathrm{f} \pm 0.01$ & $7.1 \mathrm{~g} \pm 0.05$ & $4.8 \mathrm{~d} \pm 0.01$ \\
\hline $\mathrm{PSB}_{1} \mathrm{P}_{0}$ & $2.8 d \pm 0.04$ & $4.5 \mathrm{ef} \pm 0.03$ & $6.7 d \pm 0.03$ & $7.8 \mathrm{f} \pm 0.01$ & $5.1 \mathrm{~d} \pm 0.05$ \\
\hline $\mathrm{PSB}_{1} \mathrm{P}_{1}$ & $3.4 b \pm 0.03$ & $4.8 b c \pm 0.03$ & $7.2 b \pm 0.05$ & $9.4 c \pm 0.03$ & $6.2 b \pm 0.03$ \\
\hline $\mathrm{PSB}_{1} \mathrm{P}_{2}$ & $3.2 b c \pm 0.06$ & $4.6 \mathrm{de} \pm 0.02$ & $7.0 \mathrm{c} \pm 0.04$ & $8.3 \mathrm{de} \pm 0.04$ & $5.7 c \pm 0.06$ \\
\hline $\mathrm{PSB}_{1} \mathrm{P}_{3}$ & $3.1 c \pm 0.03$ & $4.7 c d \pm 0.06$ & $6.9 c \pm 0.06$ & $8.5 d \pm 0.05$ & $5.6 c \pm 0.05$ \\
\hline $\mathrm{PSB}_{8} \mathrm{P}_{0}$ & $2.9 \mathrm{~d} \pm 0.05$ & $4.4 \mathrm{f} \pm 0.02$ & $6.6 \mathrm{~d} \pm 0.01$ & $8.1 \mathrm{e} \pm 0.02$ & $5.7 c \pm 0.03$ \\
\hline $\mathrm{PSB}_{8} \mathrm{P}_{1}$ & $3.6 \mathrm{a} \pm 0.02$ & $5.1 \mathrm{a} \pm 0.05$ & $7.8 a \pm 0.06$ & $10.5 a \pm 0.06$ & $6.9 \mathrm{a} \pm 0.01$ \\
\hline $\mathrm{PSB}_{8} \mathrm{P}_{2}$ & $3.4 b \pm 0.06$ & $4.9 b \pm 0.03$ & $7.6 \mathrm{a} \pm 0.03$ & $9.7 b \pm 0.06$ & $6.7 a \pm 0.06$ \\
\hline $\mathrm{PSB}_{8} \mathrm{P}_{3}$ & $\begin{array}{c}3.2 \mathrm{c} \pm 0.04 \\
* *\end{array}$ & $\begin{array}{c}4.8 \mathrm{bc} \pm 0.06 \\
* *\end{array}$ & $\begin{array}{c}7.3 \mathrm{~b} \pm 0.05 \\
* *\end{array}$ & $\begin{array}{c}9.3 c \pm 0.03 \\
* *\end{array}$ & $\begin{array}{c}6.7 \mathrm{a} \pm 0.06 \\
* *\end{array}$ \\
\hline
\end{tabular}

The figures in the column are the mean value of 3 replicates \pm Standard Error (SE)

** Significant at $\mathrm{p}<0.01$. Figures in a column followed by same letter(s) are not varied significantly $(\mathrm{p}<0.05)$

$\mathrm{PSB}_{0}=$ no inoculation of seeds with bacteria; $\mathrm{P}_{0}=$ no $\mathrm{P}$ fertilization; $\mathrm{P}_{1}=0.5 \% \mathrm{P}$ as TSP; $\mathrm{P}_{2}=0.5 \% \mathrm{P}$ as $\mathrm{Ca}_{3}\left(\mathrm{PO}_{4}\right)_{2} ;$ and $\mathrm{P}_{3}=0.5 \% \mathrm{P}$ as $\mathrm{AlPO}_{4}$.

Table 3. Interaction effect of PSB inoculation and different sources of $P$ on shoot dry weight, root dry weight and nutrient contents in wheat seedlings

\begin{tabular}{|c|c|c|c|c|c|c|c|c|}
\hline \multirow{2}{*}{$\begin{array}{c}\text { PSB inoculants } \times \\
\text { levels of } P \text { interaction }\end{array}$} & \multirow{2}{*}{$\begin{array}{l}\text { Shoot dry } \\
\text { weight (g) }\end{array}$} & \multirow{2}{*}{$\begin{array}{c}\text { Root dry } \\
\text { weight (g) }\end{array}$} & \multicolumn{3}{|c|}{$\begin{array}{c}\text { Nutrient contents in } \\
\text { shoots }\end{array}$} & \multicolumn{3}{|c|}{$\begin{array}{c}\text { Nutrient contents in } \\
\text { roots }\end{array}$} \\
\hline & & & $\% N$ & $\% \mathrm{P}$ & $\% \mathrm{~K}$ & $\% N$ & $\% \mathrm{P}$ & $\% \mathrm{~K}$ \\
\hline $\mathrm{PSB}_{0} \mathrm{P}_{0}$ & $0.60 \mathrm{e}$ & 0.07 & $0.81 \mathrm{~g}$ & $0.09 \mathrm{fg}$ & $1.12 \mathrm{i}$ & $0.50 \mathrm{j}$ & $0.02 \mathrm{i}$ & $0.41 \mathrm{~g}$ \\
\hline $\mathrm{PSB}_{0} \mathrm{P}_{1}$ & $0.62 \mathrm{e}$ & 0.09 & $0.92 \mathrm{e}$ & $0.11 \mathrm{f}$ & $1.16 \mathrm{i}$ & $0.52 \mathrm{i}$ & $0.04 \mathrm{~h}$ & $0.46 \mathrm{f}$ \\
\hline $\mathrm{PSB}_{0} \mathrm{P}_{2}$ & $0.62 \mathrm{e}$ & 0.10 & $0.88 \mathrm{ef}$ & $0.09 \mathrm{fg}$ & $1.19 \mathrm{~h}$ & $0.61 \mathrm{~h}$ & $0.07 \mathrm{~g}$ & $0.43 \mathrm{e}$ \\
\hline $\mathrm{PSB}_{0} \mathrm{P}_{3}$ & $0.59 \mathrm{e}$ & 0.06 & $0.85 f g$ & $0.10 \mathrm{f}$ & $1.13 \mathrm{i}$ & $0.72 \mathrm{~g}$ & $0.09 \mathrm{f}$ & $0.42 \mathrm{~g}$ \\
\hline $\mathrm{PSB}_{1} \mathrm{P}_{0}$ & $0.74 \mathrm{bcd}$ & 0.12 & $1.16 \mathrm{e}$ & $0.21 \mathrm{~cd}$ & $1.67 \mathrm{~g}$ & $1.07 \mathrm{f}$ & $0.17 \mathrm{~cd}$ & $0.51 \mathrm{~d}$ \\
\hline $\mathrm{PSB}_{1} \mathrm{P}_{1}$ & $0.77 \mathrm{ab}$ & 0.19 & $1.43 \mathrm{a}$ & $0.27 b$ & $2.43 b$ & $1.22 \mathrm{a}$ & $0.21 \mathrm{a}$ & $0.55 \mathrm{c}$ \\
\hline $\mathrm{PSB}_{1} \mathrm{P}_{2}$ & $0.70 \mathrm{~d}$ & 0.16 & $1.20 \mathrm{~d}$ & $0.22 \mathrm{c}$ & $2.13 \mathrm{e}$ & $1.13 \mathrm{~d}$ & $0.18 \mathrm{bc}$ & $0.47 \mathrm{e}$ \\
\hline $\mathrm{PSB}_{1} \mathrm{P}_{3}$ & $0.70 \mathrm{~cd}$ & 0.18 & $1.19 \mathrm{~d}$ & $0.17 \mathrm{e}$ & $1.93 \mathrm{f}$ & $1.16 \mathrm{c}$ & $0.16 \mathrm{~d}$ & $0.44 \mathrm{f}$ \\
\hline $\mathrm{PSB}_{8} \mathrm{P}_{0}$ & $0.76 \mathrm{abc}$ & 0.17 & $1.32 \mathrm{bc}$ & $0.29 \mathrm{~b}$ & $2.46 \mathrm{~b}$ & $1.19 \mathrm{~b}$ & $0.14 \mathrm{e}$ & $0.59 b$ \\
\hline $\mathrm{PSB}_{8} \mathrm{P}_{1}$ & $0.81 \mathrm{a}$ & 0.14 & $1.36 \mathrm{~b}$ & $0.32 \mathrm{a}$ & $2.61 \mathrm{a}$ & $1.18 \mathrm{~b}$ & $0.19 b$ & $0.63 a$ \\
\hline $\mathrm{PSB}_{8} \mathrm{P}_{2}$ & $0.74 \mathrm{bcd}$ & 0.15 & $1.17 d$ & 0.20 cde & $2.34 \mathrm{~d}$ & $1.15 c$ & $0.18 \mathrm{bc}$ & $0.55 \mathrm{c}$ \\
\hline $\mathrm{PSB}_{8} \mathrm{P}_{3}$ & $0.71 \mathrm{~cd}$ & 0.13 & $1.29 \mathrm{c}$ & 0.18 de & $2.37 \mathrm{c}$ & $1.11 \mathrm{e}$ & $0.14 \mathrm{e}$ & $0.50 \mathrm{~d}$ \\
\hline Level of Significance & $* *$ & NS & $* *$ & $* *$ & $* *$ & $* *$ & $*$ & $* *$ \\
\hline
\end{tabular}

The figures in the column are the mean value of 3 replicates.

Figures in a column followed by same letter/s are not varied significantly $(\mathrm{p}<0.05)$

${ }^{* *}=$ Significant at $\mathrm{p}<0.01,{ }^{*}=$ Significant at $\mathrm{p}<0.05$. NS $=$ Not significant

\section{Growth of the PSB at varying $\mathrm{pH}$}

The most superior five PSB isolates were grown in PVK broth medium with varying levels of $\mathrm{pH}$ (5.5 to 8.5) up to 8 days to see their growth (optical density, OD values) and the change of the $\mathrm{pH}$ values in culture medium. Time-course OD values revealed that the inoculated 

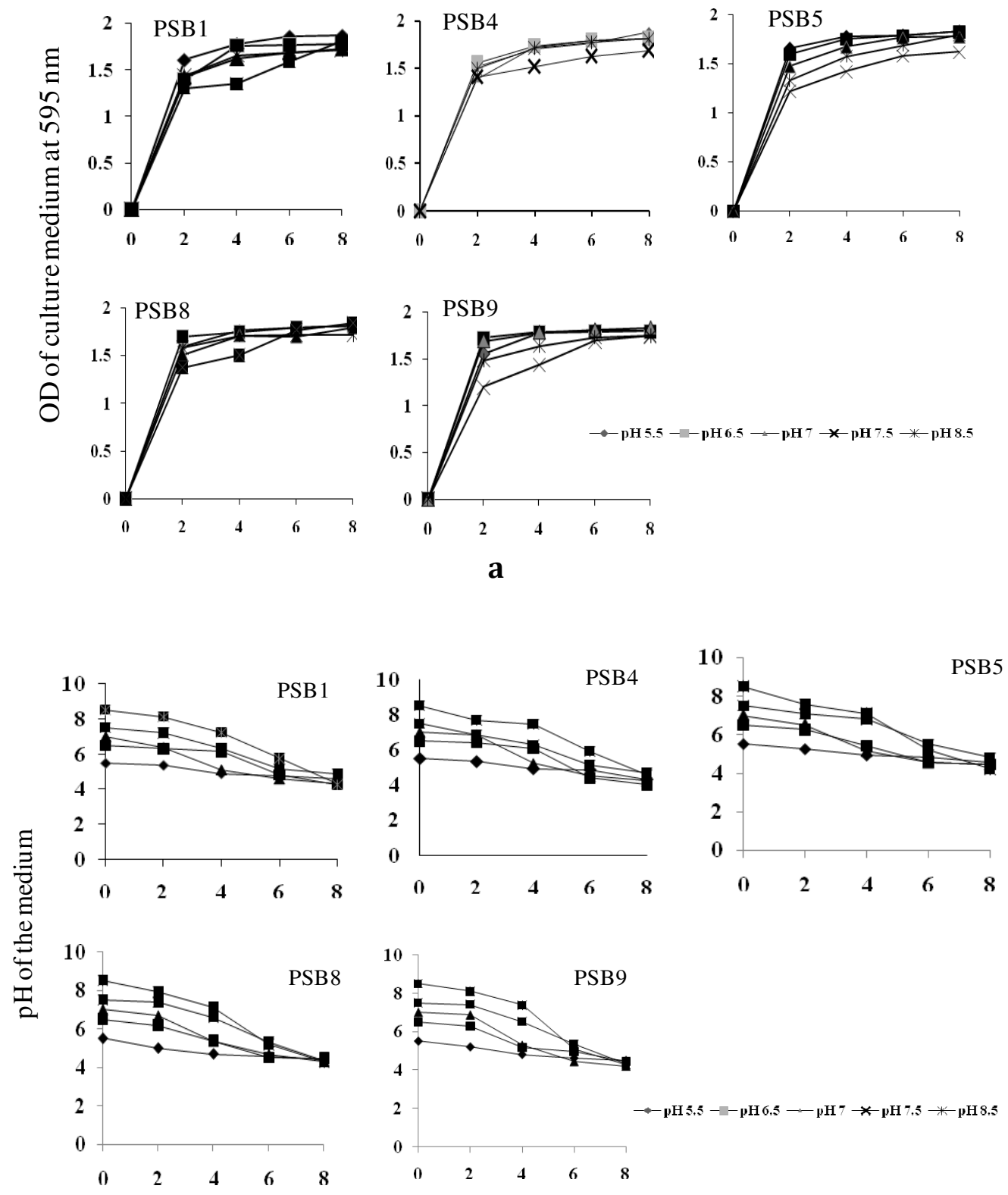

Days after inoculation

b

Fig. 1. Changes of the growth of 5 superior PSBs represented by the optical density (a) and the $\mathrm{pH}$ value of the culture medium (b) with time of inoculation in Pikovskaya's broth medium

bacterial strains showed more or less a steady growth on time (Fig. 1a). At pH 5.5, the PSB4 displayed its highest growth (OD, 1.883) followed by the PSB1 (OD, 1.870). Similarly, PSB5 displayed its highest growth (OD, 1.835) at pH 5.5. On the other hand, PSB8 exhibited highest growth (OD, 1.845) at $\mathrm{pH} 7.5$, while PSB9 exhibited its highest growth (OD, 1.832) at pH 7.0.

The $\mathrm{pH}$ value of the culture medium of all rhizoplane bacteria was decreased with time at $\mathrm{pH}$ ranged from 5.5 to
8.5 (Fig. 1b). These results indicate that the PSB strains are likely to secrete organic acids into the medium to solubilize tricalcium phosphate.

\section{Performance of PSB isolates on growth of wheat seedlings}

Shoot and root length: Table 2 shows that shoot lengths varied significantly by the effects of PSB inoculation at different days after inoculation (DAI) (i.e. 5, 10, 15 and 20 days). The PSB8 produced the highest shoot length at 5 DAI $(2.90 \mathrm{~cm})$ and at harvest $(8.10 \mathrm{~cm})$ in seedlings 
obtained from seeds previously treated with this bacterium. On the other hand, PSB1 produced the highest shoot length at $10 \mathrm{DAI}(4.50 \mathrm{~cm})$ and at $15 \mathrm{DAI}(6.70 \mathrm{~cm})$. Other treatments were also influenced the shoot lengths of wheat seedlings in similar manners. As expected, shoot lengths were gradually increased with the age of wheat seedlings irrespective of the treatments. Like shoot lengths, the root lengths also significantly $(\mathrm{P}<0.05)$ varied in seedling obtained from seeds treated with both PSB inoculants (PSB1 and PSB8) (Table 2).

Shoot and root dry weight: Inoculation of PSB significantly enhanced the shoot dry weight of wheat seedlings compared to uninoculated control $\left(\mathrm{PSB}_{0}\right)$ (Table $3)$. The treatment PSB8 produced the maximum shoot dry weight $(0.76 \mathrm{~g})$, which was superior to other treatments (Table 3). Our results showed that there was no significant variation in shoot dry weight due to the effect of different sources of $P$ (Table 3 ). The root dry weights did not vary significantly due to the effect of inoculation of phosphate solubilizing bacteria. On contrary, there was significant variation in root dry weight due to the effect of different sources of $\mathrm{P}$ (Table 3 ). The treatment $\mathrm{P}_{2}$ produced highest value of root dry weight $(0.10 \mathrm{~g})$ (Table 3$)$, which was superior to other treatments.

\section{Effect of PSB inoculation on nutrient contents of wheat} tissues

Contents of nitrogen $(\mathrm{N})$, phosphorus $(\mathrm{P})$, and potassium $(\mathrm{K})$ in shoot and root tissues of wheat seedlings varied significantly upon inoculation of PSB strains (Table 3). The inoculation of PSB8 produced the highest contents of $\mathrm{N}, \mathrm{P}$ and $\mathrm{K}$ in both shoot and root tissues of wheat seedlings (Table 3). On the other hand, the results on the interaction effect of inoculation of PSB and different sources of $P$ showed significant variation (Table 3 ). The combined treatment of bacterial strain and sources of P (PSB1P1) showed the highest value for $\% \mathrm{~N}$ in shoot and $\% \mathrm{~N}$ and $\% \mathrm{P}$ in roots, respectively (Table 3 ). Similarly, the $\mathrm{PSB}_{1}$ treatment produced the highest value for $\% \mathrm{P}$ and $\% \mathrm{~K}$ for shoot tissues and $\% \mathrm{~K}$ for root tissues. The interaction of bacterial inoculation along with comparatively soluble source of $\mathrm{P}$ significantly increased the contents of nutrients in wheat tissues as compared to the other treatment combinations.

\section{Molecular identification of PSB8}

The best performing isolate PSB8 was identified as Pseudomonas sp. based on comparison of its 16S rRNA gene sequence data with known bacteria sequences in NCBI database using BLASTN. The 16S rRNA gene sequence data of PSB8 showed only 94\% similarity with strains of Pseudomonas sp. Therefore, PSB8 seemed to be a new species as its $16 \mathrm{~S}$ rRNA gene sequence data showed less than $97 \%$ similarity to the known Pseudomonas sp.

\section{Discussion}

In the present study, we isolated 9 PSB from the rhizoplane of wheat. These isolates displayed varying levels of phosphate solubilization in both agar and broth assays probably through secretion of organic acids. Two superior isolates (PSB1 and PSB8) also tested on vegetative growth and nutrient uptake by wheat seedlings. Significant enhanced shoot and root growth and increased nutrient contents in tissues of wheat were recorded when seedlings were grown from seeds previously treated with PSB8 compared to PSB1 and control treatment. The PSB8 tentatively identified as Pseudomonas sp. through $16 \mathrm{~S}$ rRNA gene sequencing. Our results indicate that PSB8 is a potential phosphate solubilizer, which could be utilized as a bioinoculant of $\mathrm{P}$ nutrition in wheat in soils under high $\mathrm{pH}$. Solubilizations of insoluble phosphate in calcareous soils and $\mathrm{P}$ nutrition in various crops by Pseudomonas spp. have been reported by many investigators (Islam \& Hossain, 2012). This report identified a potent strain of Pseudomonas sp. for the first time from the rhizoplane of wheat grown in Bangladesh.

Our wheat PSB strains displayed consistent performances in solubilizing tricalcium phosphates in both agar and broth culture assays (Table 1). Similar consistent results of phosphate solubilization by PSB were also observed by earlier investigators (Nautiyal, 1999; Islam et al., 2007; Sarker et al., 2012). Optical density of culture medium revealed that the wheat rhizoplane PSB exhibited almost similar growth at $\mathrm{pH}$ ranging from 5.5 to 8.5. However, most of the bacterial isolates grew well in slightly acidic conditions ( $\mathrm{pH} 5.5-\mathrm{pH}$ 6.5). This is reasonable because these bacteria were isolated from the wheat grown in upland soils having pH 5.7. Although, the mechanisms of phosphate solubilization by the bacterial isolates was not clear in our current study, decrease in the $\mathrm{pH}$ value of the culture medium recorded by the isolated PSB indicating secretion of organic acids into the medium for tricalcium phosphate solubilization. The secretion of organic acids such as gluconic, 2-ketogluconic, lactic, isovaleric, isobutyric, acetic, oxalic, citric acid etc. by phosphate solubilizing bacteria have been well documented (Rodriguez \& Fraga, 1999; Vessey, 2003; Thakuria et al., 2004; Islam \& Hossain, 2012).

One of the interesting findings of our study is that seedlings obtained from seeds previously inoculated with PSB8 significantly enhanced shoot and root growth of wheat. Furthermore, not only $\mathrm{P}$ but also some other nutrient elements in plant tissues were increased in PSB8 treated wheat seedlings indicating better nutrient uptake by the plants due to bacterial inoculation. The solubilization of $\mathrm{P}$ in the rhizosphere is the most common mode of action implicated in plant growth promoting rhizobacteria such as Pseudomonas spp. that increases the nutrient availability to host plants (Cattelan, Hartel, \& 
Fuhrmann, 1999; Richardson, 2001; Islam \& Hossain, 2012). Several earlier studies showed that phosphate solubilizing rhizobacteria enhance the growth and yield of many economically important crops (de Freitas, Banerjee, \& Germida, 1997; Rodriguez \& Fraga, 1999; Nautiyal et al., 2000; Vazquez, Holguin, Puente, Lopez-Cortez, \& Bashan, 2000; Islam et al., 2007; Islam \& Hossain, 2012).

Another important finding of the current study is that the $16 \mathrm{~S}$ rRNA gene sequence data of PSB8 displayed only 94\% similarity to a plant-associated Pseudomonas sp. As less than 97\% 16S rRNA gene sequence similarity is indicative of a new species, our potent phosphate solubilizer, PSB8 isolated from wheat seem to be a new species under the genus of Pseudomonas. A further molecular-based systematic study including DNA-DNA hybridization and submission of sequence data in the Genbank are needed to confirm the identity of this strain at the species level.

In the current study, we observed that the vegetative growth (shoot and root length, shoot and root dry weights) and nutrient contents of the wheat seedlings were increased significantly after inoculation of seeds with the bacterial isolates. Increased $P$ uptake was also found of both rice and wheat when PSB were applied with rock phosphates (Sharma \& Prasad, 2003; Vyas \& Gulati, 2009). They also found growth promotion and higher nutrient uptakes in response of PSB inoculation in the cereals. In addition to $P$ solubilization, we can not exclude the possibility of the involvement of nitrogen fixation and secretion of phytohormones by the bacterial inoculant PSB8 for promotion of growth and nutrient uptake by wheat seedlings (Islam \& Hossain, 2012).

In conclusion, this study successfully isolated nine PSB from the rhizoplane of wheat grown in slightly acidic soils in Bangladesh. These PSB displayed promising effects in solubilization of phosphate from insoluble tricalcium phosphates in both agar and broth assays. One of the isolate, Pseudomonas sp. PSB8 significantly enhanced growth and nutrient uptake by wheat seedlings. This study should be further extended to investigate the potential of PSB8 under field conditions before considering its practical use as an alternative to synthetic superphosphate fertilizer for low input sustainable wheat production.

\section{Acknowledgments}

The authors are thankful to the World Bank for financial support through a sub-project CP \# 2071 to the Department of Biotechnology, Bangabandhu Sheikh Mujibur Rahman Agricultural University, Bangladesh.

\section{References}

Abd-Alla, M. H. (1994). Phosphatases and the utilization of organic phosphorus by Rhizobium leguminosarum biovar viceae. Letters in Applied Microbiology, 18, 294-296.

Afzal, A., \& Asghari, B. (2008). Rhizobium and phosphate solubilizing bacteria improve the yield and phosphorus uptake in wheat (Triticum aestivum). International Journal of Agriculture and Biology, 10, 85-88.

Alam, M. S., Talukder, N. M., Islam, M. T., \& Rahman, A. (2008). Rhizoplane bacteria as phosphate Solubilizing agent on phosphorus nutrition of rice. Bangladesh Journal of Agricultural Science, 35: 181-188.

Ashrafuzzaman M., Hossen, F. A., Ismail, M. R., Hoque, M. A., Islam, M. Z., Shahidullah, S. M., \& Meon, S. (2009). Efficiency of plant growth promoting rhizobacteria (PGPR) for the enhancement of rice growth. African Journal of Biotechnology, 8(7): 1247-1252.

Busman, L., Nalepa, P., \& Dobryniewska, M. (2009). The Nature of Phosphorous in Soils. University of Minnesota Extension WW-06, 795- 576.

Cattelan, A. J., Hartel, P. G., \& Fuhrmann, J. J. (1999). Screening for plant growth promoting rhizobacteria to promote early soybean growth. Soil Science Society of America Journal, 63, 1670-1680.

de Freitas, J. R., Banerjee, M. R., \& Germida, J. J. (1997). Phosphate solubilizing rhizobacteria enhance the growth and yield but not phosphorus uptake of Canola (Brassicanapus L.). Biology and Fertility of Soils, 24, 358-364.

Edi Premono, M., Moawad, A. M., \& Vlek, P. L. G. (1996). Effect of phosphate-solubilizing Pseudomonas putida on the growth of maize and its survival in the rhizosphere. Indonesian Journal of Agricultural Science, 11, 13-23.

Fankem, H., Nwaga, D., Deubel, A., Dieng, L., Merbach, W., \& Etoa, F. X. (2006). Occurrence and functioning of phosphate solubilizing microorganisms from oil palm tree (Elaeis guineensis) rhizosphere in Cameroon. African Journal of Biotechnology, 5, 2450-2460.

Griffith, D. B. (2009). Efficient fertilizer use - Phosphorus. Scientia Agricola, 433, 23-67.

Gull, M., Hafeez, F. Y., Saleem, M., \& Malik, K. A. (2004). Phosphorus uptake and growth promotion of chickpea by co-inoculation of mineral phosphate solubilizing bacteria and a mixed rhizobial culture. Australian Journal of Experimental Agriculture, 44, 623-628.

Hilda, R., \& Fraga, R. (2000). Phosphate solubilizing bacteria and their role in plant growth promotion. Biotechnology Advances, 17, 319-359.

Islam, M. T., Deora, A., Hashidoko, Y., Rahman, A., Ito, T., \& Tahara S. (2007). Isolation and Identification of Potential Phosphate Solubilizing Bacteria from the Rhizoplane of Oryza sativa L. cv. BR29 of Bangladesh. Zeitschrift für Naturforschung C, 62, 103-110.

Islam, M. T., \& Hossain, M. M. (2012). Plant Probiotics in Phosphorus Nutrition in Crops, with Special Reference to Rice. In: D. K. Maheshwari (Ed.), Bacteria in 
Agrobiology: Plant Probiotics (pp. 325-363), Springer, Berlin Heidelberg.

Jones, D. L., \& Darrah, P. R. (1994). Role of root derived organic acids in the mobilization of nutrients from the rhizosphere. Plant Soil, 166, 247-257.

Khiari, L., \& Parent, L. E. (2005). Phosphorus transformations in acid light textured soils treated with dry swine manure. Canadian Journal of Soil Science, 85, 75-87.

Nautiyal, C. S. (1999). An efficient microbiological growth medium for screening phosphate solubilizing microorganisms. FEMS Microbiology Letters, 170, 265-270.

Nautiyal, C. S., Bhadauria, S., Kumar, P., Lal, H., Mondal, R., \& Verma, D. (2000). Stress induced phosphate solubilization in bacteria isolated from alkaline soils. FEMS Microbiology Letters, 182, 291-296.

Olsen, S. R., Col, C. V., Watanable, F. S., \& Dean, L. A. (1954). Estimation of available phosphorus in soil by extraction with sodium bicarbonate. U.S. Dept. Agri. Cire, 929.

Page, A. L., Miller, R. H., \& Keeney, D. R. (1982). Methods of soil analysis, Part-2. American Society of Agronomy, Inc: Madi, USA.

Pikovskaya, R. I. (1948). Mobilization of phosphorus in soil in connection with vital activity of some microbial species. Microbiology, 17, 362-370.

Rahman, A., Talukder, N. M., \& Islam, M. T. (2005). Screening phosphate solubilizing bacteria from rhizoplane of tomato. Bangladesh Journal of Progressive Science and Technology, 4, 1-6.

Richardson, A. E. (2001). Prospects for using soil microorganism to improve the acquisition of phosphorus byplants. Australian Journal of Plant Physiology, 28, 897-906.

Rodriguez, H., \& Fraga, R. (1999). Phosphate solubilizing bacteria and their role in plant growth promotion. Biotechnology Advances, 17, 319-339.

Sarker, A., Islam, M. T., Biswas, G. C., Alam, M. S., \& Talukder, N. M. (2012). Screening for phosphate solubilizing bacteria inhibiting the rhizoplane of rice grown in acidic soil of Bangladesh. Acta Microbiologica et Immunologica Hungarica, 59(2), 199-203.

Sharma, S. N., \& Prasad, R. (2003). Yield and P uptake by rice and wheat grown in a sequence as influenced by phosphate fertilization with diammonium phosphate and Mussoorie rock phosphate with or without crop residues and phosphate solubilizing bacteria. The Journal of Agricultural Science, 141, 359-369.

Thakuria, D., Talukdar, N. C., Goswami, C., Hazarika, S., Boro, R. C., \& Khan, M. R. (2004). Characterization and screening of bacteria from rhizosphere of rice grown in acidic soils of Assam. Current Science, 86(7), 978-985.

Vazquez, P., Holguin, G., Puente, M. E., Lopez-Cortez, A., \& Bashan Y. (2000). Phosphate solubilizing micro-organisms associated with the rhizosphere of mangroves in a semi arid coastal lagoon. Biology and Fertility of Soils, 30, 460-468.

Vessey, J. K. (2003). Plant growth promoting rhizobacteria as biofertilizers. Plant Soil, 255, 571-586.

Von Uexkull, H. R., \& Mutert, E. (1995). Global extent, development and economic impact of acid soils. Plant Soil, 171, 1-15.

Vyas, P., \& Gulati, A. (2009). Organic acid production in vitro and plant growth promotion in maize under controlled environment by phosphate-solubilizing fluorescent Pseudomonas. BMC Microbiology, 9, 174.

Yadav, K. S., \& Dadarwal, K. R. (1997). Phosphate solubilization and mobilization through soil microorganisms. In: Dadarwal, R. K. (Ed.), Biotechnological Approaches in Soil Microorganisms for Sustainable Crop Production (pp. 293-308). Scientific Publishers, Jodhpur, India. 